\title{
THE IMPORTANCE OF DEVELOPING FOREIGN LANGUAGE COMPETENCES FOR MILITARY CADETS
}

\author{
Assoc. prof. Dr. Dileta Jatautaitė, Assoc. prof. Dr. Jelena Kazimianec
}

The General Jonas Žemaitis Military Academy of Lithuania

\begin{abstract}
Foreign language competences for the militarypersonnel of Lithuania and NATO are essential in sustaining National Security of the alliance especially by effectively performing their military duties that include not only specific military art but also administrative and managemental. The Military Academy of Lithuania is a unique higher educational institution that prepares specialists in administration, management, and other fields. Therefore, being a cadet of the Academy, he/she acquires all the necessary competences to obtain proficiency in these fields. However, the cadets of the Academy considerably need foreign language competences so that they could actively, successfully, and professionally conduct their duties not only locally but also participating internationally in various military organizations and missions. Thus, in many cases military's success in multinational operations very often depends on soldiers' ability to communicate and express themselves in English or any other foreign language. In this "global village" it is practically inconceivable to make career without the knowledge of the English or any other foreign language. Thus, the aim of the research is to analyze the role of foreign language competencies acquired at the Lithuanian Military Academy where cadets obtain qualifications and foreign language competences needed for successful career making, National and International security. Therefore, the objective of the research is how theoretically and practically resolve the issue of developing new linguistic competences in foreign languages necessary for MAL cadets through analyses of the results of the questionnaire.
\end{abstract}

Keywords: National Security, military personnel, foreign language competences, multilinguistic communication; language proficiency, STANAG 6001, national security

Introduction. Today's military establishment, its active duty, reserve, and civilian personnel, must be trained and ready to absorb the world with an appreciation of diverse cultures and to communicate directly with local and foreign populations. Acquired foreign language competences may save lives of the military especially when they are performing various traditional combat missions, just as they are identified as critical for performing irregular warfare missions. Therefore, they can save the lives of the military personnel and can greatly reduce the risk to the indigenous, non-combatant populations that the military may be trying to protect or keep peace. Possessing good foreign languages competences, the military personnel can operate with a powerful instrument in influencing a mission's 
outcome in their favor. The Department and the Services (2008) have undertaken numerous initiatives, but there are still left some critical unresolved questions. Consequently, the Department of Defense of the USA finds a big challenge to achieve a common understanding of the importance of acquiring foreign language competences needed by modern military personnel. If an individual does not know, for example, English, he/she can endanger not only himself but the whole military mission. Moreover, he/she cannot successfully seek for career which requires critical-thinking skills and a sense of international-mindedness. In fact, he/she is simply sidetracked in a world where the official language of science, internet, management, military herein is English. Consequently, those who speak more than one language are more creative, adapt better to the labor market, more successfully climb up the career ladder in both civil and military structures and organizations. Furthermore, in the development of multi-communication, continuous learning, and comprehension in the global world, it is crucial to learn multiple thoughts and opinions through new language competences. With the multi-linguistic communication, for instance, the cadets from the Military Academy of Lithuania, professional guards of National Defense system, are put forward with the necessity to acquire all-round requirements through foreign language competences so that they could successfully maintain National and International Security and keep law and order if it is necessary.

Hence, the European Pillar of Social Rights states as its first principle that everyone has the right to high quality and inclusive education, training, and lifelong learning to maintain and acquire skills that allow full participation in society and successful transitions in the labor market. It also states the right of everyone "to timely and tailor-made assistance to improve employment or self-employment prospects, to training and re-qualification, to continued education and to support for job search" (Council recommendation, 2018). Therefore, a high-quality curriculum should be the one built on high expectations, aligned with state standards, and highly rigorous. Encouragement of development foreign language competences is one of the aims of the vision towards a European Education Area that would be able "to harness the full potential of education and culture as drivers for jobs, social fairness, active citizenship as well as means to experience European identity in all its diversity" (Council recommendation, 2018).

In 2006, the European Parliament and the Council of the European Union adopted a Recommendation on key competences for lifelong learning. In that Recommendation the Member States were asked 'to develop the provision of key competences for all as a part of their lifelong learning strategies, comprising their strategies for achieving universal literacy, and use the "Key Competences for Lifelong Learning - A European Reference Framework" (2018).

The definition of the set of key competences needed for individual fulfilment, health, employability, and social inclusion were designed not only by societal and economic developments, but also by various initiatives in Europe during the last 
decade. Special attention was given to improving basic skills, investing in language learning, improving digital and entrepreneurial competences, the significance of common values in the functioning of EU societies, and motivating more young people to engage in science related careers. These developments are reflected in the Reference Framework (Council recommendation, 2018).

The aim of the research is to develop second foreign language competences acquired by cadets at the Military Academy of Lithuanian.

The object of the research is the development of the second foreign language competences acquired by cadets at the Military Academy of Lithuanian.

The problem of the research is that the cadets of the Military Academy of Lithuania do not have adequate and sufficient competences of foreign languages so that they could professionally and resourcefully execute their military duties as much as necessary to secure National and Multinational NATO Security.

The objective of the research is how theoretically and practically resolve the issue of developing new linguistic competences in foreign languages necessary for MAL cadets through analyses of the results of the questionnaire.

Methods of the research: analysis of scientific literature and documents, questionnaire survey, synthesis, interpretation, the structural equation modelling technique was applied to evaluate the causal model and confirmatory factor analysis to examine the reliability and validity of the measurement model; the research on the attitude of cadets to foreign languages learning: the foreign language learning case was conducted.

The Methodology of the Research. It is apparent that besides the English other foreign language competences are critical capabilities necessary for today's Lithuanian and NATO military personnel who face the challenges of our modern existing security environment. Only a small part of today's military is proficient in a few foreign languages for up till now there has been no comprehensive, systematic approach to developing and training not only English standard (STANAG 6001) but equally other foreign languages expertise and standards. This is a serious national security challenge which, for example, led the Department of Defense of the USA to examine what the Department of Defense is doing to address the need for these capabilities. The military's lack of foreign language competences reveals a serious problem facing the nation. The Department of Defense of the USA uncovered the pitfalls that the USA military educational system faces. It does not place a priority on the widespread teaching of foreign languages, not to mention the less commonly taught languages needed for today's military force. Hence, the Department of Defense recruit linguistically able personnel and greatly increases the Department's challenge. Accordingly, the Department finds itself in the unlikely position of advancing a national educational agenda that encourages the military of the USA to recognize the importance of various foreign language competences, not only to meet national security needs, but for the United States to remain competitive in the global marketplace. (DLI Annual Program Review, 2007). 
There is still an obvious gap between the knowledge of the English and other foreign languages among the military personnel of Lithuania. That is why it causes various problems in communication with NATO and EU partners. Language competences require a lot of time and effort to achieve high level of language proficiency. It is of theoretical and practical significance to discuss in this article the way the cadets of the Military Academy of Lithuania are trained to English and other foreign language competences necessary for successful service in Lithuanian and NATO HQ, institutions, and missions. Therefore, it is significant to define that the cadets of the Military Academy of Lithuania are a part of the military personnel that Lithuanian Military comprises. Furthermore, the Military Academy of Lithuania is supposed to be the modern preparatory higher educational school that trains the personnel capable to communicate with comprehensive English and other languages in high quality and ability, which will certainly promote cadets to further construction of the new-type military personnel training system.

Therefore, competencies of English and other foreign languages are essential for basic capabilities of the contemporary cadets of the Lithuanian Military Academy to successfully perform their administrative duties as a part of public administration as well. Hence, it is necessary to construct technologically and intellectually advance military forces possessing advance competences and capable to implement linguistic competences needed for Lithuania and NATO countries' personnel to cope with most challenging tasks. The report to the 19th National Congress of the CPC states: "In this crucial period of our new history, the responsibilities and missions of our armed forces have been expanding, from guarding our borders to participating in $\mathrm{UN}$ peacekeeping forces and international medical assistance; from disaster relief at home to fighting Somali piracy; from domestic military training to multinational joint military exercises and international military contests; a first-rate army needs not only first-rate weapons and first-rate military talent, but also firstrate language and communication skills, especially English (2008)" In recent years, Lithuania, being a part of NATO international forces, is increasing the number of military personnel in various military and administrative missions comprising various foreign elements, new and higher requirements that are stimulating Lithuanian personnel to acquire advance and skillful competences of English and other foreign language competences which have become an inevitable necessity to possess in order to effectively perform administrative and organizational duties of the institutions. Most of the military personnel in Lithuania obtain the necessary qualifications and training at the Military Academy which guarantees the learners excellent performance of various competences in public administration. However, a great number of NATO military Academies have their own way of interpretation and adaptation of teaching methodology of the English and other foreign languages for the military cadets. Therefore, the Military Academy of Lithuania, being a member of NATO and EU higher education system, successfully function due to the longterm adoption of the general foreign language teaching methodology in military 
university programs (ERASMUS+). However, the Military Academy of Lithuania as well as a great number of NATO and EU Military Academies have their own way of interpretation and adaptation of teaching of the English and other foreign languages for the military cadets. Consequently, this methodology very often experiences deficiencies of clear military application guidance in terms of teaching content and teaching methods. There is almost no research on how to cultivate unanimously accepted and standardized teaching methodology and syllabus content (except EMILYO). The policy of language teaching is based only on BILC and EU Commission recommendations on how to obtain foreign language levels after assessing the competences of language proficiency of military students and cadets; though, there is a clear policy in assessing and testing standards with the application of STANAG 6001 that is regulated by BILC Bureau for International Language Coordination which has the consensus of how to assess and test the English and some of the other languages but not to promote the transformation of English teaching to military application. In May 2018, the China Military Website, for example, claimed that "national defense language capability" is an "important standard" for building a world-class military" (Wen-hui, Song Mei, 2020). Moreover, the leaders of Chinese army, who are a competing rival of NATO, emphasize the importance of foreign language competences as "important weapon" for winning future wars (2020). In the development of multi-communication, continuous learning, and comprehension in the global world, it is necessary for MAL cadets to learn multiple thoughts and acquire new language competences. Thus, with the multi-linguistic communication military cadets are put forward with the necessity acquire all-round requirements for the foreign language ability. That is why it is so important to evaluate and scrutinize the role of second foreign language competencies acquired at the Lithuanian Military Academy for executing their duties and responsibilities of excellence.

Therefore, researchers from different countries are exploring various aspects of the concept of competence. For example, competences in higher education are explored by Jucevičienė and Lepaitè (2002), Bergan and Damian (2010), Hadiyanto (2010), Lozano, Peris, Aristizabal and Hueso (2012), Guščinskienė and Čiburienė (2016), Želvys and Akzholova (2016), Adam (2010), Hyland (2010), Deca (2010), Klemenčič (2010), etc. Moreover, measurement of competencies in higher education were analyzed by Blömeke, Zlatkin-Troitschanskaia and Fege (2013), Zlatkin-Troitschanskaia, Shavelson and Kuhn (2015). Moreover, competence-based competences in higher education were scrutinized by Bergsmann, Schultes, Winter, Schober and Spiel (2015); the aspect of multilingualism was analyzed by Tuomaite (2012), Užpalienè and Vaičiūnienė (2012), Jatautaite, D. Kazimianec J. (2019). Furthermore, foreign language competences were explored by Morekevičienè (2012), Tuomaitė (2014), Žegūnienè and Parišauskienè (2014), Pukevičiūtè (2015), Balčiūnaitienė (2016), Tuomaitė and Zajankauskaitė (2017), Jatautaite, D. Kazimianec J. (2018), and many others. After acquiring the above-mentioned 
competencies, in today's 21st century, it becomes easier for the representatives of new military generation cadets participate in lifelong learning, to integrate successfully in Society, to be competitive in the labor market, to communicate and cooperate with people of different nations and cultures, to ensure the security and democratic stability of their homeland and become an instrument enabling people to take advantage of the opportunities offered by the global world (Sanjeev, 2006).

Furthermore, linguistic competencies, integrated in the work of daily routine of the military, are also vital for the country's development of economic system, social development, and ensuring National Security. Moreover, National Security system critically needs perfect language competencies as foreign languages proficiency is directly related to successful career duty performing and excellent career making in the military. In addition, according to Koning (2009), National Security is a fast-growing and exciting career field for those who possess good and sustainable foreign language competences. Moreover, Kohn (2012) emphasizes that in the USA, a large focus of the initiative is focused on training language competences by considering them as a "critical-need" to national security, which include Arabic, Chinese, Japanese, Korean, Russian, Indic, Persian, and Turkic languages families, among others" (Khan, 2012).

In this regard, there is a great number of scientific publications are dealt in this by United States researchers. Müller (1986), Wible (2009), Khan, (2012), Koning (2009) are most cited for their analyzing and scrutinizing National Security issues and challenges. Furthermore, Müller, who studied the historical experience of the U.S. military during World War I and World War II, experience in Vietnam, Korea, and others, stated that "Perhaps no other profession outside that of diplomacy is as concerned with the relationship between a nation and its neighbors as is the military" (Müller, 1986).

Rendering B. Sanjeev's opinion from University of Allahabad, it is clear to notice his accentuation on the significance of foreign language competencies in sustaining National Security as knowledge of foreign languages directly correlate with the country's National Security (2006). Though, English has practically become the only one unified world language which is spoken by every sixth person on earth, but it is unusual in the fact that most speakers are not 'native'. Of the approximately 1.5 billion people who speak English, less than 400 million use it as a first language. That means over 1 billion speak it as a secondary language (ICEF Monitor, 2019).

The English Proficiency Index has published its latest research on where English is learned around the world and quality of teaching in each country to find the places with the highest proficiency of English as a second language. It is not surprising that Europe has so many nations near the top of the Index given historical trade links with the UK and the fact that it is one of three 'working languages', along with French and German, of the European Commission. The report found that better English in a country correlates with higher income, higher levels of 
innovation and a better quality of life. In nearly all countries surveyed, women had stronger English skills than men (World Economic Forum, 2021).

All these increasingly important languages do not take away from the fact that French remains an official language in many countries, and it is a fast-growing language. Therefore, Forbes Magazine (2019) reports that, "French is growing in the fastest-growing areas of the world, particularly sub-Saharan Africa. The latest projection is that French will be spoken by 750 million people by 2050." In the same Forbes Magazine (2019) it is also noted that despite the urgency some now feel to learn Mandarin Chinese given China's rise over the past decade, there are factors that may reduce demand for the language going forward: "the other mooted language of the future, Mandarin, despite being excruciatingly hard to learn for most Westerners, will probably not be that given China's certain demographic slide. Meanwhile, French will be present on all continents, and particularly predominant in a continent that, by 2050, should be a fast-growing economic powerhouseAfrica." The world's changing language landscape - (ICEF Monitor, 2019).

But of course, the landscape of global power and business has changed intensely, with the past decade demonstrated by the striking rise of China and other BRICS countries: Brazil, Russia, India, and South Africa and the Middle East (where the population is expected to double to over 1 billion inhabitants by 2100). By far, English continues to be the world's most studied language. However, these factors have increased the reflection aligns of many prospective language learners across the world - and thus expanded the range of prospects for language givers in a rising list of countries (2019).

Therefore, in many cases military's success in the world in multinational operations very often depends on the soldiers' ability to communicate and express themselves in English as well as other languages. In this "global village" it is practically inconceivable to make career without the knowledge of the English language. If a human being does not know English which requires critical-thinking skills and a sense of international-mindedness, he or she is simply sidetracked in a world where the official language of science, internet, military is English. Abbott (2012) stated that "what we do know, though, is that about 75 percent of the world does not speak English. And if they do speak it, they don't speak it at a very high level of proficiency. So, we also know that a lot of business doesn't get done at the board table, at the business table, it gets done through building relationships. And I think that's another reason why our (The USA) country needs to really expand its language capabilities and acquire new competences" (2012). It means that lead with Language competences aims to raise awareness of the importance of language learning in a global economy. In a globalized world, those who can move seamlessly across cultural and linguistic boundaries will have many more opportunities and learning methods go beyond the classroom walls. As a result of all the above-mentioned aspects, the value of foreign language competences leads to National Security and security awareness. 
For example, training system of West Point Military Academy (West Point Academy, 2021) entails teaching personnel, professional degree types, general curriculum setting, professional course requirements, extracurricular activities, professional measurement indicators and graduates' prospects, summarizing its outstanding features and its enlightenment to the construction of foreign language courses in military and local universities. West Point Military Academy (2021) emphasizes the importance of language teacher integration program into military context. Thus, the enlightenment to military academies from the training system of foreign language professionals in West Point military Academy is based on foreign language teachers in military academies who should be further optimized, who should take turns to experience life in the army or take up temporary posts in the army and engage in activities related to foreign languages (2021). In addition, it is likewise emphasized that foreign language courses in military colleges and universities should be militarized. Therefore, West Point Military Academy recommends other higher education military institutions not to copy the curriculum of foreign language courses in local colleges and universities, but to unify and standardize foreign language syllabus on military content. Moreover, the commanders of the Academy assert not directly to transfer the design of language courses but to follow just the internal logic of foreign language subjects. They recommend endorsing only taking language proficiency as an example, since various jobs involve different levels of listening, speaking, reading, writing, and translating skills and competences. Therefore, in limited time, emphasis can be laid on the integrated five skill development (2021).

It is obvious that Lithuanian cadets, officers as well as civilians who operate for the MAL or National Defense System of Lithuania are also forced to study foreign languages almost all their life in terms of European Union's Lifelong Learning Programmed. Lifelong Learning Programmed is essential if anyone wants to lead shifts with challenges of the global world and sustain his/her or the county's security and stability (Smith, 2014).

\section{Foreign language competences as a part of National Security}

Knowledge of a foreign language, while being a significant instrument of communication, must be viewed as an enabler sustaining and guaranteeing safety and security of Lithuania and NATO allies. Here in, Thompson (2011) in his article "The Pentagon's Foreign-Language Frustrations" marks that "learning the language will not only help one learn about that culture but be able to operate more effectively once immersed in it. Improving our language skills may lead to more effective and efficient techniques for building the capacity of our current and future partners and reduce the need for deployments of robust US forces" (2011). Leon Panetta in the same article stated that the language and cultural training is a key to U.S. global economic and security interests and that "languages are the key 
to understanding that world. If we are going to advance stability in some of the countries we are fighting in today, we have to be able to understand what motivates those countries, what motivates their people, and to understand their culture, beliefs, faiths, ideologies, hatreds and loves. Strong language ability is necessary to do that" (Jatautaite, Kazimianec, 2018).

Moreover, U.S. Department of Education, Office of Postsecondary Education, Enhancing Foreign Language in the United States realized the preliminary results of the National Security language initiative which asserts that there is no single universally accepted definition of National Security. The variety of definitions provides an overview of the various usages of this concept. National Security is regarded as the enhancements in military power to protect the Nation. These efforts are also seen as attaining military power that a State's Political Will could be imposed in international arena centered on its military power. Basically, the National Security is explained as an 'ability of a Country/Nation' to protect the internal values from the external threats or aggression. Term ability of a country encompasses every dimension of the National Security i.e., Sociocultural, Economic, Political and Military (U.S. Department of Education, 2008).

The definitions and interpretations continue to undergo changes as the international community experiences political, economic, social, environmental and 'inter-state-relations' transitions.

The relationship between languages and National Security is not new, but it has received increased attention in the security mindful early years of the twentyfirst century.

Where the relationship between language and security has been highlighted, this tends to have made little progress ahead of arguments that language competence is crucial in the context of National Security (Brecht, 2003, Brecht 2000, Rivers, 2002, Sapolsky, 2002).

Subsequently, the Mission of West Point Academy is "to develop, through education in the languages, cultures and regions of the world, commissioned leaders of character so that each is able to thrive in complex international security environments and is prepared to serve around the globe throughout a career of service to the nation. One of the best ways to set yourself up for success in college, the military, and your life beyond service is to achieve fluency in another language" (West Point Academy, 2021).

The nationally ranked Department of Foreign Languages at West Point offers cadets the opportunity to study in-demand languages, as well as study abroad programs and travel to other countries to practice language skills.

However, in the USA, the place of language teaching, learning and other linguistic competences in, military studies at higher education have increased significantly following failures in intelligence prior to and following the $9 / 11$ attack and there has been growing awareness of the importance of language issues involved in the process of military higher education (Müller, 2002). 
Conflict management-oriented language planning typically covers three main areas of activity: intelligence gathering and analysis; covert communication and military co-ordination.

"Open the World" is the motto of the Foreign Language Department at West Point. Col. Baskerville (West Point Academy, 2021) from West Point Academy explained that every cadet, regardless of their major, is required to take at least two semesters of a foreign language during their time at the Academy. Along with facilitating good communications, knowing another language develops complex problem-solving skills, encourages creative thinking, and develops leaders of character" (West Point Academy, 2021). In addition, he stated that West Point Academy follows the words of Nelson Mandela who expressed his message to the students perfectly: "If you talk to a man in a language, he understands it goes to his head. If you talk to him in his language, it goes to his heart." (2021).

\section{Why is the demand for NATO countries to know languages at minimum level II according to STANAG 6001?}

The House Armed Services Subcommittee on Oversight and Investigations chose to examine the Department of Defense foreign language program's "transformation" efforts to improve language skills, regional expertise, and cultural awareness capabilities within the Department, not only because of the historic challenge that this transformation represents, but because this is an area with profound implications for the nation's success at adapting to the realities of irregular warfare (the Department, DOD, 2007).

Whereas before, language competences were viewed as critical primarily for intelligence analysts, Foreign Area Officers, and other regional specialists. Therefore, today language skills are seen by Department of Defense of the USA as critical operational capabilities - just as important as weapons - on the battlefield and across the entire array of Departmental missions (2007). Foreign language competences primarily belong to very specific elements of the force until now and only theses days they have become a critical need of competences necessary for the general-purpose forces. The term "language professionals" refers to military personnel who possess a verified foreign language capability and require this capability to perform their primary functions. This category includes, for example, officers, who have a thorough awareness of a region based on "indepth and personal knowledge, training, and experience." (2007). Importantly, the officers are required to have proficiency in at least one foreign language to perform their primary function by enchanting security assistance groups and as defense attachés at embassies, the Army, and the Marine Corps.

The perception here is that if the armed forces want successfully to operate together in a coordinated way, they need a common language - that is a common language is linked with effective communication. 
The first language planning decision in this context is the choice of which language will be used as the common language.

In real life, this decision is commonly made in relation to the language of the most powerful country involved, which, as in the case of NATO's PfP (partnership for peace), is commonly English (Department of Defense, 2007).

For example, owing Lithuania's Case: the choice of English is usually treated as a trouble-free given for NATO as the following quotation shows: "for a country like Lithuania, whose geography compels it to base national warfare on light infantry, the top priority in the defense policy should be the development of welltrained and competent units of junior and senior officers able to communicate with NATO in terms of speaking the same language (English) and working on the same radio frequencies" (Krivas, 1999).

In the same article, Krivas underscores the naturalness of English in Lithuania's context because the NATO official language training is a sine qua non in the whole interoperability related work. The primary focus is, of course, on English as the language of NATO integrated military structure (1999). Besides English, military co-operation takes place between France and Ukraine which entails the teaching of French in Ukrainian military colleges (Ambassade Française en Ukraine, 2007). Moreover, France also supports the teaching of French in Czech military colleges (Ambassade Française en République tchèque, 2007). These activities are also included as activities in relationship to PfP. Similarly, Germany offers German language training for military cooperation through the Militärische Ausbildungshilfe (Bundesministerium der Verteidigung, 2002).

What concerns the State Education Strategy of the Republic of Lithuania of 2003-2012, the attention was drawn to cultural and communicative competences by emphasizing today's people necessity to have a good command of foreign languages (Seimas of the Republic of Lithuania, 2003). However, by summarizing all the results of the implementation of this Strategy, it was stated that the realization of the Strategy was not fully implemented.

Thus, it was recommended that "the knowledge of two or three foreign languages should mandatory become a natural part of higher education ". However, during the above-mentioned period, only an average of one-fifth of students studied two or more foreign languages in higher education institutions of Lithuania". (Implementation of the State Education Strategy 2003-2012, (2012). Moreover, the State Education Strategy for 2003-2012 states that Lithuania did not focus enough on language competence (State Education Strategy for 20032012).

Therefore, the notion of the linguistic competence is explained as a competence of an individual's knowledge, abilities, skills, attitudes, personal characteristics, and values that determine the expression of his/her qualification or ability to act effectively (Guščinskiene, Čiburienè, 2016). Therefore, the term linguistic competence refers to the unconscious knowledge of grammar that 
allows a speaker to use and understand a language. Also known as grammatical competence or language in contrast with linguistic performance. Furthermore, Noam Chomsky calls linguistic competence that is not considered an evaluative term. $\mathrm{He}$ refers it to the innate linguistic knowledge that allows a person to match sounds and meanings. In "Aspects of the Theory of Syntax", Chomsky wrote, "We thus make a fundamental distinction between competence (the speaker-hearer's knowledge of his language) and (the actual use of language in concrete situations) performance (1965)."

Moreover, John Benjamins claims that "the linguistic competence of a human being should accordingly be identified with that individualıs internalized (program) for production and recognition. While many linguists would identify the study of this program with the study of performance rather than competence, it should be clear that this identification is mistaken since we have deliberately abstracted away from any consideration of what happens when a language user attempts to put the program to use. A major goal of the psychology of language is to construct a viable hypothesis as to the structure of this program" (Kac, 1992).

In addition, Kristin Denham and Anne Lobeck try to explain that even the native speakers of a language do not know the language any better than any other speaker in terms of linguistic competence (2010).

A variety of competencies that are developed at a higher education are designed in a set of unified components. They comprise professional, social, intercultural, communication, information management, change, language competencies that can be seen in Figure 1.

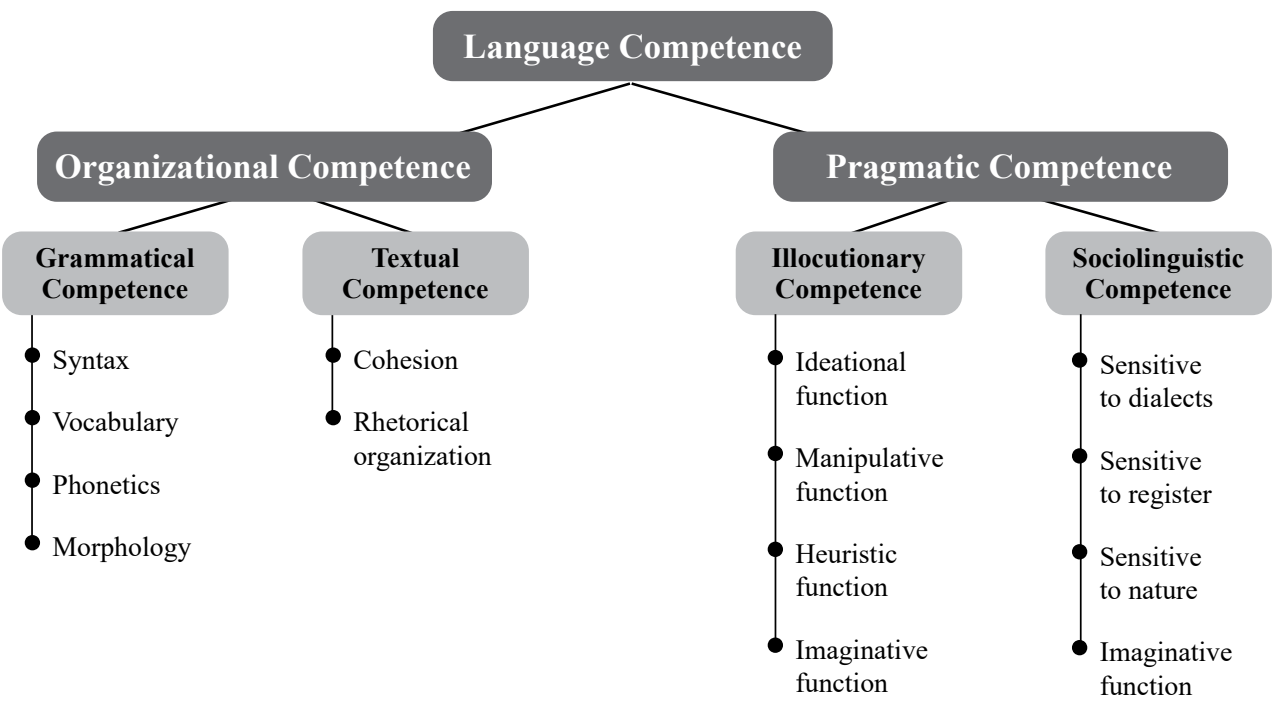

Figure 1. Components of Language Competence (Bachman, 1990, p.87)

Source: Bachman, L.F. 1990. Fundamental considerations in language testing.

Oxford: Oxford University Press. 
Only in recent years the Department has explicitly identified foreign language competences and regional expertise as "critical warfighting skills" to be integrated into future operations "to ensure that combat forces deploy with the essential ability to understand and effectively communicate with native populations, local and government officials, and Coalition partners when in theater." (2007). In addition, Deputy Secretary Gordon England included strengthening foreign language and cultural awareness capabilities among the Department's top 25 transformation priorities. The Department cites many recent strategic-level documents, such as the Quadrennial Defense Review, the National Security Strategy and related Strategic Planning Guidance, the Irregular Warfare Execution Roadmap, the Building Partnership Capacity Roadmap, the Strategic Communications Roadmap, and the DOD directive Military Support for Stability, Security, Transition, and Reconstruction (SSTR) Operations as recognizing the need for increased foreign language, cultural awareness, and regional expertise capabilities (2007). Two recent high-level documents highlight the change that the emergence of irregular warfare has had on the Department's thinking. The 2008 National Defense Strategy identifies improving the U.S. Armed Forces' proficiency in irregular warfare as the Department of Defense's top priority. The Irregular Warfare Joint Operating Concept proposes an expanded role for general purpose forces in supporting and executing irregular warfare missions, which in the past were carried out by special operations forces. The Irregular Warfare Joint Operating Concept calls on the Services to train the force so that "a pool of linguistically and culturally educated personnel capable of operating in priority countries" exists throughout the joint force, not just the special operations force. The Irregular Warfare Joint Operating Concept also asserts that irregular warfare will not be won based solely on military prowess. Rather, it will be won by understanding social dynamics, such as tribal politics, religious influences, and cultural mores. "People, not platforms and advanced technology will be the key to [Irregular Warfare] success" (Department of Defense, 2007).

In 2005, the Department set a new goal of "general professional proficiency" (Level 3) for language professionals in reading, listening, and speaking. Before 2005 , military linguists, were expected to achieve limited working proficiency (Level 2) in reading, speaking, writing, and listening. The Department set this new goal largely due to pressure from the National Security Agency (NSA), the main "employer" of military officers.

A STANAG, or STANdardisation AGreement, is an international military standard created by the North Atlantic Treaty Organization (NATO) for regulating equipment, procedures, tactics, training and just about everything that affects how armed forces from different countries work together on operations and exercises. In other words, STANAG 6001 is a language proficiency scale designed to allow comparisons of language ability in different countries. The scale consists of a set of descriptors with proficiency skills broken down into 5 levels, coded 1 through 5 . They are defined as follows (Table 1.): 
Table 1. The scale consisting of a set of descriptors with proficiency skills

- Level 0 No practical proficiency

- Level 1 Elementary

- Level 2 Fair (Limited working)

- Level 3 Good (Minimum professional)
- Level 4 Very good (Full professional)

- Level 5 Excellent (Native/Bilingual)

Source: http://www.campaignmilitaryenglish.com/Course/grammarpractice1.htm

Language proficiency is recorded with a profile of 4 digits indicating the specific skills in the following order: Listening, Speaking, Reading, Writing. For example, an individual with the level SLP 3232 has level 3 in Listening, level 2 in Speaking, level 3 in Reading and level 2 in Writing. This number of four digits is preceded by the code letters SLP which is to indicate that the profile shown is the Standardized Language Profile. There is no one official exam for the STANAG 6001 levels and countries which use the scale produce their own tests and are responsible validating their tests in terms of the STANAG 6001 levels. The original version of STANAG 6001 was created in 1976 (Edition 4, 12 October 2010) Language Proficiency Levels. In 2003, BILC which is a consultative and advisory body for language training matters in NATO, released a document on the standardization of language training and testing called NATO STANAG (Standard agreement) 6001 explaining the details of language proficiency levels that military personnel are supposed to have to participate in joint international missions. The NATO member countries deploying personnel to joint missions have been following the standards since 2003. There are currently 48 nations using STANAG 6001 criteria in their language systems. They are supposed to establish their own training structure, design their syllabi and teaching materials, implement a testing framework, develop tests, and monitor training outcomes. The goal is to improve English language skills of all personnel who are to cooperate with NATO forces in Partnership for Peace (PfP) operations, exercises, and training with NATO staff. These military should be able to communicate effectively in English with added emphasis on operational terminology and procedures. Such goals state that nations should not only address special measures to increase in general the language proficiency of current officers and NCOs but also the integration of adequate language training as part of their normal career development to ensure adequate language proficiency for future military personnel (Scott 2009).

Currently, numerous language performance standards exist alongside each other. In other words, the various guidelines attempt to assess what individuals can and cannot do with the target language regardless the curriculum. For example, the ACTFL stands for the American Council on the Teaching of Foreign Languages. Thus, ACTFL is "a national organization dedicated to the improvement and expansion of the teaching and learning of all languages at all levels of instruction 
throughout the U.S." standards resulted from national efforts (ACTFL, 2012), the STANAG 6001 standards are used within supranational organizations (NATO, 2014), and others have been developed by testing organizations in the form of rating scales. Since different organizations use different scales, it is not easy for test takers or test users to interpret scores and compare them with other tests (Gomez, Noah, Schedl, Wright, Yolkut, 2007). Hence, in this case there is a table specially designed to compare the equivalence of score and level interpretation of NATO STANAG 6001 Language Standards and Common European Framework (Cef) and The Comparison of Their Current Status.

\section{Comparison Chart}

\section{STANAG 6001 - Levels - International exams}

\begin{tabular}{|c|c|c|c|c|c|c|}
\hline \multicolumn{5}{|c|}{ Scales } & \multicolumn{2}{|c|}{ Tests } \\
\hline $\begin{array}{c}\text { STANAG } \\
\text { 6001 } \\
\text { Standardized } \\
\text { agreement } \\
6001(1976) \\
\\
\text { NATO \& } \\
\text { BILC }\end{array}$ & \multicolumn{2}{|c|}{$\begin{array}{c}\text { CEF } \\
\text { Common European Framework } \\
\text { COE: Council of Europe }\end{array}$} & $\begin{array}{c}\text { ALTE } \\
\text { Scale } \\
\\
\text { ALTE: } \\
\text { Association } \\
\text { of Language } \\
\text { Testers in } \\
\text { Europe }\end{array}$ & & $\begin{array}{l}\text { Cambridge } \\
\text { ESOL } \\
\\
\text { Cambridge } \\
\text { ESOL } \\
\text { Examinations } \\
\text { (formerty } \\
\text { UCLES) }\end{array}$ & $\begin{array}{c}\text { IELTS } \\
\text { The } \\
\text { British } \\
\text { Council, } \\
\text { IDP \& } \\
\text { Cambridge } \\
\text { ESOL }\end{array}$ \\
\hline $\begin{array}{c}\mathbf{5 5 5 5} \\
\text { Native/bilingual } \\
\end{array}$ & & & & & (DIPLOMA) & 9 \\
\hline \multirow{3}{*}{$\begin{array}{c}\mathbf{4 4 4 4} \\
\text { Fully } \\
\text { Professional }\end{array}$} & C2 Mastery & \multirow{3}{*}{$\begin{array}{l}\text { Proficient } \\
\text { User }\end{array}$} & \multirow{2}{*}{$\begin{array}{c}\mathbf{5} \\
\text { Good User }\end{array}$} & \multirow{2}{*}{$\begin{array}{c}\text { Upper } \\
\text { Advanced }\end{array}$} & \multirow{2}{*}{ CPE } & 8 \\
\hline & \multirow[b]{2}{*}{$\begin{array}{l}\text { C1 Effective } \\
\text { Operational } \\
\text { Proficiency }\end{array}$} & & & & & 7 \\
\hline & & & $\begin{array}{c}\mathbf{4} \\
\text { Competent } \\
\text { User }\end{array}$ & $\begin{array}{l}\text { Lower } \\
\text { Advanced }\end{array}$ & CAE & 6 \\
\hline 3333 & B2+ Vantage+ + & \multirow{4}{*}{$\begin{array}{l}\text { Independent } \\
\text { User }\end{array}$} & 3 & Upper & & \\
\hline $\begin{array}{l}\text { Minimum } \\
\text { Professional }\end{array}$ & B2 Vantage & & $\begin{array}{l}\text { Independent } \\
\text { User }\end{array}$ & Intermediate & FCE & 5 \\
\hline \multirow{2}{*}{$\begin{array}{c}\mathbf{2 2 2 2} \\
\text { Limited } \\
\text { Working }\end{array}$} & B1+ Threshold & & 2 & Lower & & \\
\hline & B1 Threshold & & $\begin{array}{l}\text { Threshold } \\
\text { User }\end{array}$ & Intermediate & PET & 4 \\
\hline 1111 & A2+ Waystage + & \multirow{4}{*}{$\begin{array}{l}\text { Basic } \\
\text { User }\end{array}$} & \multirow{2}{*}{$\begin{array}{c}\mathbf{1} \\
\text { Waystage } \\
\text { User }\end{array}$} & \multirow{2}{*}{ Elementary } & \multirow{2}{*}{ KET } & 3 \\
\hline Elementary & A2 Waystage & & & & & 2 \\
\hline \multirow{2}{*}{$\begin{array}{c}\mathbf{0} \\
\text { Unscaled }\end{array}$} & \multirow{2}{*}{$\begin{array}{c}\text { A1 } \\
\text { Breakthrough }\end{array}$} & & \multirow{2}{*}{$\begin{array}{c}\mathbf{0} \\
\text { Breakthrough }\end{array}$} & \multirow{2}{*}{ Beginner } & & 1 \\
\hline & & & & & & 0 \\
\hline
\end{tabular}

Figure 2. NATO STANAG 6001 Language Standards and Common European Framework (Cef) and The Comparison of Their Current Status

Source: Campaign Military English: The Course - Teacher's Book

To better understand the scope and details of linguistic shortfalls, Congress of the USA included a requirement in the National Defense Authorization Act for Fiscal Year 2008 requiring the Department to submit annual reports on the topic concerning the linguistic competences acquired by the military personnel. 


\section{The results of the attitude of cadets to foreign language competencies}

The purpose of the research was to design the questionnaire survey to find out about the attitude of cadets to foreign language learning competences acquired at the Military Academy of Lithuania: the foreign language learning case. Hence, based on this analysis the results of the questionnaire it is necessity to state that there is a need of modernization of the content of the development of foreign language competencies in a higher education institution. It is verified, that there is a great demand for modernization and approvals of content components for further research to solve the existing problem. During the last 2018 - 2019 semester of the second foreign language subject (July 8, 2019) training, the second-year cadets of the MAL were asked to fill out the questionnaire. The interviewees were 74 cadets (I and II year) from the Military Academy of Lithuania who studied English, German, French and English.

All the respondents studied the second foreign language from level B1 to B2 (English) and from A1 to B2 (French, Russian and German) according to the Common European Framework of Reference for Languages (CEFR) which is an international standard for describing language ability (Jatautaite, Kazimianec, 2018).

The research instrument consisted of 9 questions aimed at finding out the reasons of foreign language learning by cadets:

1. What led you choose a second foreign language?

2. What was your level of proficiency in this language?

3. When did you start learning the language course at the Academy?

4. What level of the chosen language would you like to achieve at the end of your studies?

5. What kind of possibilities do you imagine of applying the second foreign language while serving in the army and making a career?

6. How many semesters or how many hours per semester, in your opinion, should be given to a cadet to study a second foreign language at the MAL?

7. Being a learner of a foreign language would you recommend other cadets to study it?

8. If you had a chance to choose to go to study any foreign language in the future, would you study it?

9. Would you choose another higher institution in the absence of the possibility to study the foreign language according to the approved university study program?

\section{Results of the Research}

The responding rate was $65.52 \%$.

The opinions of 74 cadets were distributed as follows: 
$68 \%$ of respondents asserted that a foreign language should be studied at least four semesters.

$6 \%$ of respondents answered that foreign languages should be thought the whole period of Bachelor studies.

$64 \%$ respondents expressed certainty and necessity to have at least 48 hours per semester to study the foreign language.

According to the results, the researchers concluded that there should be more attention paid to cadets' foreign language competences at university study programs.

$71 \%$ of the respondents stated the importance of good language competences and high level (STANAG 6001) of English (II) or any other foreign language for the officers and professional soldiers who might participate in various NATO or EU international missions and operations.

$7 \%$ respondent stated they would like to learn a second foreign language at least to read and write.

$12 \%$ claimed the importance of language learning and acquisition so that they could successfully understand and be able to communicate with foreigners who speak those languages.

Evaluation and assessment standard not always reflect directly whether the soldiers participating in the test can meet the requirements of carrying out external tasks in terms of

foreign language proficiency, for example, most of our cadets and officers are still limited to daily communication, and more than $67 \%$ of them still have great difficulties in attending military meetings in English. In a survey of 74 cadets only 66.1 percent stated that their English ability was simply unable or difficult to meet job demands.

Rating Scale released the importance and need for the MAL cadets to require foreign language proficiency competences which divide, for example, English language proficiency into three stages and nine levels. The level of English language proficiency is divided into six aspects: language comprehension, language expression, pragmatic competence, language knowledge, translation competence and language use strategy (Jatautaite, Kazimianec , 2019).

\section{Conclusions and recommendations}

The results of the study show that foreign language learning and acquisition of cadets showed the importance of the English and other language competences in their career.

Cadets have a strong desire of learning other foreign languages, obtaining new competences and improving other languages.

Cadets stated the importance of possessing foreign language competences in the protection of the Homeland.

Cadets were certain that foreign language competences would provide them 
with opportunity to receive, read and comprehend information.

The study also found out that respondents through language learning get introduced to the peculiarities of the military profession and military service during their military and university studies.

Cadets attained competences enough to transfer knowledge from one context to a new one to continue learning or obtaining new competences development on their own pace.

In the time of quick development of information technology, the process to a strong military cannot be closed and self-confident but requires extensive contact with the militaries of other countries. In the process of multi-communication, continuous learning and understanding the world, it is necessary to learn multiple thoughts.

It does exist a problem that there is no significant difference in English teaching between military academies and local universities, using the same teaching materials and methods. There should be significant difference in training military cadets who might one day encounter inevitable danger and their linguistic errs might be fatal in comparison with civilians and other learners.

Due to the long-term adoption of the general foreign language teaching mode in line with the local universities, the English teaching of military academies lacks the clear military application guidance in terms of teaching content, teaching methods and assessment standards (except STANAG 6001).

Due to STANAG 6001, it has become the consensus of assessing English proficiency competences but not the teaching standards of curriculum content. Therefore, systematic project should be implemented to change teaching content by adjusting specific military teaching objectives.

Finally, it is of theoretical and practical importance to discuss the way of training the English and other foreign languages of military cadets to improve the comprehensive English quality and ability of cadets, which will certainly promote the further construction of the new-type military personnel training system of foreign language competences.

\section{Literature}

Abbott (2012) in Senate Hearing from the U.S. Government Publishing Office, p.112-663

ACTFL (2012). American Council on the Teaching of Foreign Languages 1001 N. FAIRFAX ST., SUITE 200 | Alexandria, VA 22314 ph 703-894-2900 | fax 703-894-2905 | www.actfl.org

Adam, S. (2012). Competences, learning outcomes and convergence. Higher education for modern societies-Competences and values. Ed. Bergan, S., Damian, R. Council of Europe Publishing. P. 121-135.

Ambassade Française en République tchèque. (2007) La coopération 
militaire. [Military cooperation] Retrieved 9 May, 2007, from http://www.france. cz/article.php3?id_article $=665$.

Ambassade Française en Ukraine. (2007) Présentation de la coopération militaire francoukrainienne. [Presentation on Franco-Ukrainian military cooperation] Retrieved 9 May, 2007, from http://www.ambafrance-ua.org/article. php3?id_article=13Bachman, L.F. 1990. Fundamental considerations in language testing. Oxford: Oxford University Press.

Advances in Social Science, Education and Humanities Research, volume 466

Balčiūnaitienè, A. (2016). Darnaus vystymosi kompetencijos ugdymo (si) veiksniai ir aplinka mokantis užsienio (anglų) kalbos aukštojo mokslo institucijoje. Andragogika, (1), p.177-190.

Bergsmann, E., Schultes, M. T., Winter, P., Schober, B., Spiel, C. (2015). Evaluation of competence-based teaching in higher education: From theory to practice. Evaluation and program planning, 52, p. 1-9. Available: http://www. sciencedirect.com/science/article/pii/S0149718915000270

Brecht, R.D. (2003) Language in the US Post September 11: A Practical Design for a Federal Language Strategy. University of Maryland, College Park: National Foreign Language Center.

Brecht, R.D., \& Rivers, W. P. (2000) Language and National Security for the 21stCentury: The Role of Title VI/Fulbright-Hays in Supporting National Language Capacity. Dubuque.

Brecht, Richard. Statement before the U.S. House, Armed Services Committee, Subcommittee on Oversight and Investigations, hearing on "Defense Language and Cultural Awareness Transformation: To What End? At What Cost?" Washington, D.C.: 9 July 2008.

Bowman, Tom. "Military aims to bolster language skills; Pentagon plan would spend hundreds of millions of dollars to solve problem exposed in Iraq, Afghanistan," The Baltimore Sun, 2 January 2006, 1 A.

"Bundesministerium der Verteidigung - Arbeitsschutzgesetzanwendungsverordnung vom 3. Juni 2002 (BGBl. I S. 1850)"

Chomsky, N. (1965). Aspects of the theory of syntax. M.I.T. Press.

Council Recommendation of 22 May 2018 on key competences for lifelong learning (Text with EEA relevance.) ST/9009/2018/INIT OJ C 189, 4.6.2018, p. 1-13 (BG, ES, CS, DA, DE, ET, EL, EN, FR, HR, IT, LV, LT, HU, MT, NL, PL, PT, RO, SK, SL, FI, SV).

Defense Language Institute Foreign Language Center. Annual Program Review 2007. Watsonville, CA: Printworks, April 2008. Command Plan, 2008-2012. Monterey, CA: 2008. DLIFLC Command Briefing. Briefing. 2 July 2008. Defense Language Institute Foreign Language Center, General Catalog 2006-2007. Mandarin Basic: Language Survival Guide. Monterey, CA: March 2007. "DLI Beefs Up Language Skills," U.S. Fed News Service, 29 March 2007. 
Givens, Terri E. Statement before the U.S. House, Armed Services Committee, Subcommittee on Oversight and Investigations, hearing on "DOD's Work with States, Universities, and Students to Transform the Nation's Foreign Language Capacity." Washington, D.C.: 23 September 2008.

Deca, L. (2010). Translating converging competences into the reality of teaching, learning, research, and life at higher education institutions. Higher education for modern societies-Competences and values. Ed. Bergan, S., Damian, R. Council of Europe Publishing. P.145-153.

Denham, K., Lobeck, A. (2010). Linguistics for everyone: An introduction. Boston, MA: Wadsworth, Cengage Learning. Pp. xviii, 534.

Ekrem S. Nordquist, R. (2020). Linguistic Competence: Definition and Examples. ThoughtCo, Aug. 26, 2020, thoughtco.com/what-is-linguisticcompetence-1691123.

Forbes (2019). https://www.forbes.com/

Guščinskienè, J. Čiburienè, J. (2016) Šiuolaikinès visuomenès ugdymo veiksniai. LKA. Volume 1, Issue 1

Garcia G. P., Noah, A. Schedl, M. A.,Wright, C, Yolkut, A. (2007) Proficiency Descriptors Based on a Scale-Anchoring Study of the New TOEFL iBT Reading Test. http:/mc.manuscriptcentral.com/hlaq

Guščinskienė, J., Čiburienè, J. (2016). Ugdymo dermė aukštojoje mokykloje. Šiuolaikinès visuomenès ugdymo veiksniai. T. 1, p. 13-28.

Hadiyanto, H. (2010). The Development of Core Competencies at Higher Education: A Suggestion Model for Universities in Indonesia. Available: https:// www.researchgate.net/publication/319543684_The_Development_of_Core Competencies_at_Higher_Education_A_Suggestion_Model_for_Universities_in Indonesia

Higher education for modern societies-Competences and values. (2010). Ed. Bergan, S., Damian, R. Council of Europe Publishing.

Hyland, A. (2010). Competences, learning outcomes and convergence: a case study - University College Cork. Higher education for modern societiesCompetences and values. Ed. Bergan, S., Damian, R. Council of Europe Publishing. P.135-145.

ICEF (2021). The world's changing language landscape. (ICEF Monitor, 2019)

Jatautaite, D. Kazimianec J. (2018) The Importance of Sustaining Secure Ambience for Cadets of the Military Academy of Lithuania via Balancing Emotions and Perception in Attaining Accelerated Second Language Learning and Acquisition Volume 8, Issue 2 (2018): Journal of Security and Sustainability Issues, pp. 161 https://doi.org/10.9770/jssi.2018.8.2(4)-

Jatautaite, D. Kazimianec J. (2018) The Second Foreign Language Teaching at the Military Academy of Lithuania (on the Basis of Audiovisual Method). Šiuolaikinès visuomenès ugdymo veiksniai. LKA. Volume 3, Issue 1 pp. 259-268. 
Jatautaite, D. Kazimianec J. (2019). Visual aids as a part of second language learning strategies. Šiuolaikinès visuomenès ugdymo veiksniai. LKA. T. 4, p. $165-18$

Jucevičienè, P., Lepaitè, D. (2002). Evaluatoras Feed-Back Driver: European Competences and Contemporary Training Problems. Socialiniai mokslai. Nr. 4 (36). P. 57-63.

Kac, M. B. (1992). Grammars and Grammaticality: Rule-Governed Behavior in its Syntactic Aspect. John Benjamins.

Kendall/Hunt. Brecht, R.D., \& Rivers, W.P. (2002) The language crisis in the United States: Language, national security and the federal role. In S. Baker (Ed.), Language Policy: Lessons from Global Models (pp. 76-90). Monterey, CA: Monterey Institute of International Studies.

Khan. J. M. (2012). Our Untapped Reserve and Necessity for Strengthening National Security Through Foreign Language Proficiency: "Do You Speak ? Available: http://www.culturaldiplomacy.org/academy/ content/pdf/participant-papers/2012-06-iscd-usa/Our-Untapped-Reserve-AndNecessity-for-Strengthening-National-Security-Through-Foreign-LanguageProficiency--Jameel-Khan.pdf

Krivas, A. (1999) Towards interoperability: Actions at home. Baltic Defence Review, 1, 1-7.

Klemenčič, M. (2010). Converging competences: diversity, higher education and sustainable democracy. Higher education for modern societies-Competences and values. Ed. Bergan, S., Damian, R. Council of Europe Publishing. P.153-167.

Koning, P. (2009). Using Languages in National Security. The Language Educator. February, p. 32-37. Available: https://www.actfl.org/sites/default/files/tle/ career-focus/TLE_01NatSecure.pdf

Lietuvos Respublikos Seimo nutarimas. Valstybinė švietimo 2013 - 2022 metų strategija. Žin., 2013, Nr. 140-7095.

Lietuvos Respublikos Seimo nutarimas. Valstybinès švietimo strategijos 2003 - 2012 metų nuostatos. 2003-06-30, Nr. IXP-2309 (2SP).

Lozano, J.F., Peris, J., Aristizabal, A.B., Hueso, A. (2012). Competencies in Higher Education: A Critical Analysis from the Capabilities Approach. Available: https://www.researchgate.net/publication/230545715_Competencies_in_Higher_ Education_A_Critical_Analysis_from_the_Capabilities_Approach

Modeling and Measuring Competencies in Higher Education. Tasks and Challenges (2013). Ed. Blömeke, S., Zlatkin-Troitschanskaia, O., Fege, Ch. K. J. Rotterdam/ Boston Taipei: Sense Publishers

Morkevičienė, S. (2012). (Inter) cultural reflections in teaching / learning modern greak as a foreighn language. Daugiakalbystès tyrimai: mokslinių straipsnių rinkinys [elektroninis išteklius] = Research in multilingualism: selected papers / sudaryt. N. Mačianskienė. Kaunas: Vytauto Didžiojo universitetas, p. 40-47.

Müller, K. E. (1986). Language Competence Implications for National 
Security. Published with The Center for Strategic and International Studies, Georgetown University, Washington, D.C. Available: https://www.questia.com/ library/3633810/language-competence-implications-for-national-security

Proceedings of the 2020 4th International Seminar on Education, Management and Social Sciences (ISEMSS 2020)

Pukevičiūtè, V. (2015). Mokymosi mokytis kompetencijos, mokantis užsienio kalbos, ugdymo(si) strategijos. Edukologijos inžinerijos link: teorijos ir praktikos sanglauda: mokslo studija / sudarytoja Elvyda Martišauskienè. Vilnius: Lietuvos edukologijos universiteto leidykla, 2015. p. 324-343.

Q\&A on the 19th National Congress of the Communist Party of China (From Embassy of the People's Republic of China in the Republic of South Africa)

Sanjeev, B. (2006) "National Security", Department. of Defense and Strategic Studies, University of Allahabad.

Sapolsky, R.M. (2000). Glucocorticoids and hippocampal atrophy in neuropsychiatric disorders. Arch Gen Psychiatry 57, 925-935

Seimas of the Republic of Lithuania, 2003.

Smith, K. (2019). Foreign language classes becoming scarcer. American Academy of Arts \& Sciences. February 6. Available: https://www.amacad.org/ news/foreign-language-classes-becoming-more-scarce

Song Mei, Hao Wenhui. (2020) Journal of Literature and Art Studies, October 2020, Vol. 10, No. 10, 923-928 doi: 10.17265/2159-5836/2020.10.008 A Demand Analysis and Teaching Design of English for Specific Military Purposes for Noncommissioned Officers HAO.

STANAG 6001" Language Proficiency Levels", Ed. 4. (2010). B. BILC CONSTITUTION and RULES OF PROCEDURE (rev 2007).

Statement before the U.S. Senate, Armed Services Committee, hearing on "The Future of U.S. Ground Forces: Challenges and Requirements." Washington, D.C.: 17 April 2007.

Thompson M. (2011) 40 Journal of Security and Sustainability ISSUES ISSN 2029-7017 print/ISSN 2029-7025 online

Tuomaite, V. (2012). Aukštosios mokyklos absolventų kalbiniai pasiekimai daugiakalbystės aspektu. Daugiakalbystės tyrimai: mokslinių straipsnių rinkinys [elektroninis išteklius] $=$ Research in multilingualism: selected papers / sudaryt. N. Mačianskienè. Kaunas: Vytauto Didžiojo universitetas, p. 68-82

Tuomaitè, V. (2014). Bendrosios, profesinès ir akademinės užsienio kalbos kompetencijos plètojimo aukštojo mokslo institucijoje svarba absolventų požiūriu. Kalba ir kontekstai: mokslo darbai. Vilnius: Lietuvos edukologijos universitetas. T. 6(1), 2 dalis, p. 289-299.

Tuomaitè, V., Zajankauskaitè, Z. (2017). Oral Communication in a Development in Academic Contexts. Studies About Languages = Kalbų studijos. Kaunas: KTU. Nr. 31, p. 113-129. DOI: https://doi.org/10.5755/j01.sal.0.31.19049

U.S. Department of Education (2008.) Office of Postsecondary Education, 
Enhancing Foreign Language Proficiency in the United States: Preliminary Results of the National Security Language Initiative, Washington, D.C.

Užpalienė, D., Vaičiūnienė, V. (2012). European dimension and multilingual functioning in higher education: Erasmus students' experience. Kalbų studijos = Studies about languages: taikomoji kalbotyra, sociolingvistika, kompiuterinè lingvistika, svetimujų kalbų studijos / Kauno technologijos universitetas. Humanitarinių mokslų fakultetas. Kaunas: Technologija. Nr. 20, p. 131-137.

U.S. Department of Defense, Office of the Deputy Secretary of Defense. Program Budget Decision 753, "Other Secretary of Defense Decisions." Washington, D.C.: 23 December 2004.

Valstybinès švietimo strategijos igyvendinimas 2003-2012. Medžiaga diskusijoms. (2012). Vilnius: Švietimo aprūpinimo centras.

Zlatkin-Troitschanskaia, O., Shavelson, R. J., Kuhn, C. (2015). The International State of Research on Measurement of Competency in Higher Education. Studies in Higher Education, 40(3), 393-411. Available: http://www. tandfonline.com/doi/abs/10.1080/03075079.2015.1004241

Žegunienė, V., Parišauskienė, D., Jankauskienė, B. (2014). Netradicinių (o gal tradicinių) metodų taikymas mokant užsienio kalbų kolegijoje. Verslas - studijos- mokslas 2014: Respublikinè mokslinè-praktinė konferencija: straipsnių rinkinys / Žemaitijos kolegija, Rietavo fakultetas. Rietavas: Žemaitijos kolegija, p. 102-109.

Zelvys, R., Akzholova, A. (2016). Challenges of applying competencebased learning in higher education. Acta paedagogica Vilnensia. Vilnius: Vilniaus universitetas. T. 36, p. 9-17.

Within BILC, and in some quarters of NATO, the need to assess level 4 proficiency is seen as too complex and too infrequently required to apply, but the descriptors for the four skill sets are contained in STANAG 6001 Edition 4. A BILC Study Group is attempting to resolve the quandary.

Which Countries are Best at English as a Second Language? (2021). | World Economic Forum (weforum.org)

Wible, S. (2009). Composing Alternatives to a National Security Language Policy. National Council of Teachers of English. Available: Vol. 71, No. 5 (May), p. 460-485. Available: https://www.jstor.org/stable/25652986 


\title{
KARIŪNŲ UŽSIENIO KALBŲ \\ KOMPETENCIJŲ UGDYMO SVARBA
}

\author{
Dileta Jatautaitè, Jelena Kazimianec \\ Generolo Jono Žemaičio Lietuvos karo akademija
}

\section{Santrauka}

Lietuvos ir NATO karių užsienio kalbų mokèjimas - labai svarbus saugumo komponentas, siekiant palaikyti tarptautinị Aljanso, nacionalinị saugumą ir karinio personalo profesionalumą, ypač efektyviai vykdant karines misijas, kurios apima ne tik specifinį karinio meno išmanymą, bet ir administracines bei vadybines funkcijas. Lietuvos karo akademija yra unikali aukštoji mokykla, be karinių studijų, organizuojanti universitetines studijas - rengianti administravimo ir vadybos specialistus. Todèl besimokydami Akademijoje kariūnai igyja visas būtinas kompetencijas, reikalingas būsimam karininkui, kad jis gebètų efektyviai ir kokybiškai vykdyti ịvairias pavestas užduotis. Tačiau Akademijos kariūnams taip pat reikalingos užsienio kalbų žinios ir kompetencijos, nes be jų jie negalès ne tik kokybiškai, sèkmingai ir profesionaliai atlikti savo pareigų Lietuvos kariuomenès vadavieteje ar padalinyje, bet ir efektyviai dalyvauti tarptautineje veikloje įvairiose organizacijose ir misijose. Taigi daugeliu atvejų karių sėkmė tarptautinėse operacijose dažnai priklauso nuo jų gebejjimo bendrauti ir reikšti mintis anglų ar kita užsienio kalba. Užsienio kalbų mokèjimas yra saugumo kompetencija, be kurios šiuolaikinis karininkas negalès garantuoti šalies ir NATO saugumo. Labai svarbi saugumo sąvoka kalbų kompetencijų, kurias kariūnai ịgyja mokydamiesi Lietuvos karo akademijoje, kontekste. Todèl šiame straipsnyje aptariamos ir analizuojamos šioje aukštojoje mokykloje igyjamos svarbios kariuomenès personalui kompetencijos, kurios taip pat užtikrina saugų ir kokybišką kariuomenès personalo funkcionavimą. Be to, praktiškai neịsivaizduojamas karjeros siekis neturint anglų ar kitų užsienio kalbų kompetencijų. Todèl tyrimo tikslas buvo išanalizuoti užsienio kalbų kompetencijas, igyjamas Lietuvos karo akademijoje, atlikus anketinę apklausą kariūnų, kurie mokosi ne tik anglų, bet ir kitų kalbų, kad galima būtų nustatyti šių kompetencijų svarbą nacionaliniam ir tarptautiniam saugumui užtikrinti, siekti karjeros ir t. t. Taigi tyrimo tikslas - teoriškai ir praktiškai pagrịsti užsienio kalbų kompetencijų, reikalingų LKA kariūnams, kad jie užtikrintų nacionalinị saugumą ir karinio personalo efektyvų funkcionavimą, išanalizavus anketinès apklausos rezultatus, reikšmę. 


\section{AUTORIŲ LYDRAŠTIS}

Autoriaus vardas, pavardè: Dileta Jatautaitè

Mokslo laipsnis ir vardas: socialinių mokslų daktarè, docentė

Darbo vieta ir pareigos: Generolo Jono Žemaičio Lietuvos karo akademijos Humanitarinių mokslų katedros docentė

Autoriaus mokslinių interesų sritys: psicholingvistika, glotoedukologija, edukologija, tradiciniai ir netradiciniai kalbų mokymo metodai ir metodologija, psichoedukologiniai kalbų mokymo ir išmokimo pagrindai

Telefonas ir el. pašto adresas: (8 5) 210 3560; dileta.jatautaite@mil.lt

Autoriaus vardas, pavardè: Jelena Kazimianec

Mokslo laipsnis ir vardas: humanitarinių mokslų daktarè, docentė

Darbo vieta ir pareigos: Generolo Jono Žemaičio Lietuvos karo akademijos Humanitarinių mokslų katedros docentė

Autoriaus mokslinių interesų sritys: dabartinė rusų kalba, rusų kalbos gramatika, lingvokultūrologija, svetimujų kalbų dėstymo didaktika, sociolingvistika, komparatyvistinè lingvistika

Telefonas ir el. pašto adresas: + 37068759 272; jelena.kazimianec@lka.lt

\section{AUTHORS' COVER LETTERS}

Author's name and surname: Dileta Jatautaitè

Academic degree and name: Associate Professor, Doctor

Workplace and position: The General Jonas Žemaitis Military Academy of Lithuania, Centre of Foreign languages

Author's research interests: psycholinguistics, glotoeducology, neurolinguistics, traditional and non-traditional language teaching methods and methodology, psycho-educational basis in language learning and acquisition.

Telephone and e-mail address: +370 5210 3560; dileta.jatautaite@mil.lt

Author's name and surname: Jelena Kazimianec

Academic degree and name: Associate Professor, Doctor, Lecturer

Workplace and position: The General Jonas Žemaitis Military Academy of Lithuania, Centre of Foreign languages

Author's research interests: Contemporary Russian, Russian grammar, linguacultural studies, foreign language teaching didactics, sociolinguistics, comparative linguistics.

Telephone and e-mail address: +370 5210 3560; jelena.kazimianec@lka.lt 